Published in : Ecotoxicology and environmental safety (2000), vol.

45 , iss. 1 , pp. 49-54

Status : Postprint (Author's version)

\title{
Concentration Effects of Selected Insecticides on Brain Acetylcholinesterase in the Common Carp (Cyprinvs carpio L)
}

\author{
Dembele K, Haubruge E, Gaspar C \\ Unité de Zoologie, Faculté Universitaire des Sciences Agronomiques, 2, Passage des Deportés, B- \\ 5030 Gembloux, Belgium
}

\begin{abstract}
The differential inhibition of acetylcholinesterase (AChE) by organophosphate (OP) and carbamate $(\mathrm{C})$ is followed by the distinct duration of exposure effect on common carp AChE. Hence, in the present study in vivo exposure period effect and in vitro concentration-response of chlorfenvinphos, chlorpyrifos diazinon, and carbofuran were investigated on Cyprinus carpio L. AChE. Individuals of 1year-old carp were exposed for $96 \mathrm{~h}$ to different concentrations of insecticides- after which AChE activity was measured in the brain. The highest concentrations of carbofuran $\left(2.44 \mathrm{mg} \cdot \mathrm{L}^{-1}\right)$ chlorfenvinphos $\left(2.9 \mathrm{mgL}^{-1}\right)$, and diazinon $\left(2.5 \mathrm{mg} . \mathrm{L}^{-1}\right)$ killed at] the test animals after only $4 \mathrm{~h}$, although there was no statistically significant difference from the control group's brain AChE activity. The lowest concentration significantly inhibited brain AChE after $96 \mathrm{~h}$. Chlorfenvinphos was the most potent inhibitor in vivo and chlorpyrifos the least active inhibitor after $96 \mathrm{~h}$ of exposure time. In vitro experimentation with the same pesticide indicated that several concentrations inhibited $50 \%$ of the AChE activity $\left(\mathrm{I}_{50}\right)$ ranging from $4.1 \times 10^{-7}$ to $8.12 \mathrm{X} 10^{-4} \mathrm{M}$ in both single inhibitory action and joint inhibitory effect. The results suggest that in biomonitoring programs carp brain AChE can be a good diagnostic tool for chronic OP nd C pollution.
\end{abstract}

Key Words: organophospbate; carbamate; synergy; AChE; common carp.

\section{Introduction}

The recent development of a biomarker based on the study of the biological response of organisms to pollutants has provided essential tools for the implementation of programs for contamination monitoring (Peakall and Shugart, 1991).

Organophosphate (OP) and carbamate (C) insecticides are known to disrupt transmission in the central and peripheral cholinergic nervous systems in vertebrates by inhibiting acetylcholinesterase activity (Sahib and Rao, 1980; Sharma et al., 1993). These pesticides are produced and used in large amounts, and they enter the environment in greater quantities than chlorinated hydrocarbon insecticides (Coppage and Mathews, 1974), The possible hazard of AChE-inhibiting pesticides in the aquatic environment should not be ignored, since these pesticides act as a nerve poison by inhibiting the respiration center of the brain and neuromuscular junctions of the respiratory apparatus (Coppage and Braidech, 1976).

Aquatic organisms exhibit a broad range of inhibitory response to OP and $\mathrm{C}$ pesticides, depending on the compound, exposure time, water conditions, and species (Copp-age and Mathews, 1974).

Considering the number of OP and $\mathrm{C}$ compounds and the difficulty in detecting their highly toxic oxygen analogue, measuring AChE is probably the best general indicator of serious OP and $\mathrm{C}$ pesticide pollution (Cool et al, 1976). Determination of brain AChE activity is widely used to diagnose OP and $\mathrm{C}$ poisoning (Hart, 1993). Taking into consideration that the activity of AChE is reduced to less than $50 \%$ of the normal level by OP and $\mathrm{C}$, this degree has been regarded as a good indicator of poisoning (Coppage and Mathews, 1974; Westlake et al., 1981a, b).

This article reports an investigation carried out to evaluate the concentration-response to some widely used ag-rochemical insecticides, and the length of time necessary for an in vivo inhibitory effect on carp brain AChE to occur. For testing this chlorfenvinphos, chlorpyrifos, diazinon, and car-bofuran were chosen, because these compounds are widely used in Belgium. A high density agricultural area and a river with cyprinidea coincide in Wallonia. In this region, data for 1996 indicate that the cholinesterase inhibitor concentration is estimated to be $0.17 \mu \mathrm{g}-\mathrm{L}^{-1}$, a yield higher than the WHO limit of $0.1 \mu \mathrm{g} \cdot \mathrm{L}^{-1}$. The present study evaluates the effects of agricultural pesticides on the teleosts of the river Meuse. 
Published in : Ecotoxicology and environmental safety (2000), vol.

45 , iss. 1 , pp. 49-54

Status : Postprint (Author's version)

\section{Materials and methods}

\section{Chemicals}

Commercial preparations of Birlan (244 g $\bullet \mathrm{L}^{-1}$ chlorfen-vinphos $\quad$ (2-chloro-1-(2,4-dichlorophenyl)vinyl diethyl phosphate)), Pychlorex (480 g.L ${ }^{-1}$, chlorpyrifos (0,0-di-ethyl-0-(3,5,6-trichloro-2pyridyl)-phosphorothioate)), Dis-onex (162 g $\bullet \mathrm{L}^{-1}$ diazinon (0-0-diethyl-0-(-2-isopropyl-4-methyl-6pyrimidyl)phosphorothionate)), and Curater (200 $\mathrm{g} \mathrm{L}^{-1}$ carbofuran (2,3-dihydro 2,2-dimethyl-7 benzofuranol methylcarbamate)) were purchased from Shell Chemical Co, and were used for the in vivo study. Toxicity assays were performed with stock solution prepared by dissolving $10 \mathrm{ml}$ of Birlan, Disonex, and Pychlorex in $100 \mathrm{ml}$ of ethanol, and $10 \mathrm{ml}$ of Curater in $100 \mathrm{ml}$ of distilled water. These solutions were further diluted to obtain the experimental concentrations in aquariums.

Active preparations of chlorfenvinphos (97\%), chlor-pyrifos (99\%), diazinon (98\%) and carbofuran (99\%) from Sigma Chemical Co. were used for the in vitro study. In vitro test solutions were initially prepared at $10^{-1} \mathrm{M}$ concentration in absolute ethanol. These initial solutions were further diluted to obtain final concentrations ranging from $10^{\prime 2}$ to $10^{-8} \mathrm{M}$.

The dye 5-5'-dithiobis-(2-nitrobenzoic acid) (DTNB) and the substrate acetylthiocholine chloride (AcSCh) were used to determine acetylcholinesterase activity (Ellman et a/., 1961). The chromogen was prepared as follows: $186 \mathrm{mg}$ of DTNB was mixed with $75 \mathrm{mg}$ of calcium bicarbonate and dissolved in $50 \mathrm{ml}$ of distilled water. AcSCh was diluted to $10^{-1} \mathrm{M}$ in distilled water. The chemicals were obtained from Sigma Chemical Co. Bovine serum albumin (BSA) was used for determination of protein quantity and was obtained from Bio-Rad.

\section{Biological Reagent}

Test animals were 1-year-old carp belonging to the "mirror variety." Separate groups of 400 fish, 6-10 $\mathrm{cm}$ long, were obtained from an industrial fish farm (Piscimeuse, Thiange: Belgium). Acclimatization took place in a $6 \times 3 \times 0.75-\mathrm{m}$ aquarium in the experimental piscicultural installation of the Gembloux Agricultural University (Belgium). During acclimatization the fishes were fed every $72 \mathrm{~h}$ for 12 days with Trouvit compound (Trouw, Fontaine les Vervins, France). Temperature was kept at $8^{\circ} \mathrm{C} \pm 2{ }^{\circ} \mathrm{C}$ and aeration at $0.66 \pm 0.1 \mathrm{~g} . \mathrm{L}^{-1}$ of oxygen.

The experimentation was conducted in two ways. The first was performed in vitro and the effect of chlorfenvin-phos, chlorpyrifos, diazinon, and carbofuran on AChE activity was checked, as well as the effect of the mixtures carbofuran-chlorfenvinphos, carbofuran-chlorpyrifos, car-bofuran-diazinon, and chlorfenvinphos-chlorpyrifos. Second, in vivo effects were determined by exposing groups of 10 individuals to four concentrations of each pesticide in separate $100-\mathrm{L}$ acrylic plastic aquariums. For all experiments, the static test was performed as described by the European Organization for Cooperation and Development (OCDE, 1981), modified for measuring brain AChE activity.

\section{Acetylcholinesterase Assay}

After decapitation, the fish brain was quickly removed and homogenized in a low salinity solution (LSS) containing $50 \mathrm{mM} \mathrm{MgCl} 2,10 \mathrm{mM}$ Tris-HCl, $\mathrm{pH} 7.0$, and $1 \mathrm{mg} / \mathrm{ml}$ bacitracin. The crude homogenate was centrifuged at $18,000 \mathrm{~g}$ for $15 \mathrm{~min}$ at $4^{\circ} \mathrm{C}$. The supernatant was collected for protein and AChE assays.

The protein determination was performed using the original Lowry method (Lowry et al. 1951). Twenty-five microliters of supernatant was incubated with $1125 \mu \mathrm{l}$ of folin reagent $(125 \mu \mathrm{l}$ of A and $1000 \mu \mathrm{l}$ of B). The content was then mixed and after $15 \mathrm{~min}$ of reaction the absorbance was read at 750 $\mathrm{nm}$. Brain AChE activity determination was carried out using the method of Ellman et al. (1961). The supernatant $(100 \mu \mathrm{l})$ was added to a test tube $(1.5 \mathrm{ml})$ containing $880 \mu \mathrm{l}$ of $0.1 \mathrm{M}$ phosphate buffer $(\mathrm{pH}$ 7.5), $10 \mu \mathrm{l}$ of $100 \mathrm{mM}$ DTNB, and $10 \mathrm{ul}$ of $0.1 \mathrm{M}$ acetylthiocholine chloride at $412 \mathrm{~nm}$. The contents was then mixed and the absorbance read continuously for 1 min using a Shimadzu 160A UV spectrophotometer. At least three samples were assayed for each brain. Enzyme activity was reported as millimoles of product formed per milligram protein per minute. The percentage of AChE inhibition was derived by expressing the activity levels of exposed animals as a percentage of the activity in controls. For the determination of the in vitro inhibitory effect, $10 \mu 1$ of chlorfenvinphos (97\%), chlorpyrifos (99\%), diazinon (98\%), and carbofuran (99\%) in concentrations ranging from $10^{-2}$ to $10^{-8} \mathrm{M}$ (concerning the final reaction mixture) was added to the curve for $2 \mathrm{~min}$. The absorbance was then 
Published in : Ecotoxicology and environmental safety (2000), vol.

45 , iss. 1 , pp. 49-54

Status : Postprint (Author's version)

determined at $412 \mathrm{~nm}$. The combined effect of insecticides on AChE activity was determined as follows: the two insecticides being tested were added in the curve at the same quantity and concentration; the preincubation took $2 \mathrm{~min}$. AChE activity was determined according to the method of Ellrnan et ai (1961). The I50 value was then determined by probit regression (Finney, 1971).

\section{In Vivo Study}

The experiments were conducted for 2 weeks after acclimatization. Chlorfenvinphos, chlorpyrifos, and diazinon were dissolved in ethanol and carbofuran in water. Four trial dosages were selected according to the toxicity of the pesticides on other animals described in the literature, and a preliminary experiment was conducted on carp. Every week two different concentrations of each of the four pesticides were chosen randomly with a control group. Fish were exposed to those concentrations for $96 \mathrm{~h}$. Before the end of the previous experiment (96 h), the dead fish were decapitated and AChE activity was determined.

Pesticide concentration in the water was expressed in theoretical $\mathrm{mg} \cdot \mathrm{L}^{-1}$. The analysis of residues was not performed because criteria were aimed at the duration and concentration effect on AChE inhibition. Control animals were maintained in a pesticide-free medium $(100 \mathrm{~L})$ containing $25 \mathrm{ml}$ of ethanol, because three of the four pesticides were dissolved in ethanol. After the stipulated periods the surviving fish were decapitated and the brains were removed and kept at $0^{\circ} \mathrm{C}$ for determination of AChE activity and protein quantity. $\mathrm{AChE}$ was measured even If fish died after a few hours in order to demonstrate the longer period of time necessary to exhibit significant inhibition of brain AChE, as it is generally stipulated that $\mathrm{OP}$ and $\mathrm{C}$ inhibit the respiratory center in the brain.

\section{Statistical Analysis}

The general statistical analysis was analysis of variance.

(1) Brain AChE activity of the control groups for the first 2 weeks was compared by general linear model (GLM) hierarchical method at 0.05 level of significance in order to eliminate the interference of the experimental period duration.

(b) One-tailed Dunnett's test for significant differences $(\alpha=0.05)$ between treated animals and controls (Dagnelie, 1975) was also used.

Statistical analyses were performed using Minitab statistical software.

\section{Results}

Exposure of fish to different levels of OPs chlorfenvin-phos, chlorpyrifos, and diazinon and carbofuran (C) caused severe abnormalities in their behavior, such as disequilibrium in swimming and retardation in opercula movement The test animals exhibited abnormal behavior earlier at higher than lower concentrations. With all insecticides tested, test animals died rapidly when exposed to the highest concentration.

Data on the inhibition of AChE incubated with OPs and C are provided in Figs. 1 and 2, which depict logarithmic concentration response plots for the insecticides used. Figure 1 indicate that $\mathrm{C}$ causes a more potent inhibition than OPs. This is indicated by the broad range of $\mathrm{I}_{50}$ from $4.1 \times 10^{-7}$

(carbofuran) to $8.12 \times 10^{-4} \mathrm{M}$ (chlorpyrifos), both in a single inhibitory action (Fig. 1). In Fig. 2, the presence of carbofuran induces a more rapid inhibition than that produced by OPs. Table 1 provides the $\mathrm{I}_{50}$ values for the concentration - related inhibition of $\mathrm{AChE}$.

In vitro the highest / so values were detected with chlor-pyrifos $\left(\mathrm{I}_{50}=8.12 \times 10^{-4} \mathrm{M}\right)$ and the lowest were found with carbofuran $\left(\mathrm{I}_{50}=4.1 \times 10^{-7} \mathrm{M}\right)$. The highest inhibitory effect was obtained with the mixture of carbofuran and chlorpyrifos $\left(\mathrm{I}_{50}=3.68 \times 10^{-7} \mathrm{M}\right)$ and the lowest inhibitory effect was with the mixture of two organophosphates $\left(\mathrm{I}_{50}=9.8 \times 10^{-5} \mathrm{M}\right)($ Table 1$)$.

The experiment to determine in vivo inhibition of brain AChE had a 2-week design. There were two control groups: controls- for the first week and contro!s 2 for the second week. No mortality was observed in controls. The comparison of AChE activity of the controls indicates no variability between control groups for the same week and between the 2 weeks (GLM; $d f=1, P<0.05, F=1.38$ and 2.02, respectively) (Table 2).

In the $96-\mathrm{h}$ static test, the $\mathrm{LC}_{50}$ value for chlorfenvinphos was $0.74 \times 10^{-4} \mathrm{mg} . \mathrm{L}^{-1}$ determined by probit 
Published in : Ecotoxicology and environmental safety (2000), vol. 45 , iss. 1 , pp. 49-54

Status : Postprint (Author's version)

analysis with CL (confident limit) $=95 \%$ (Raymond, 1985).

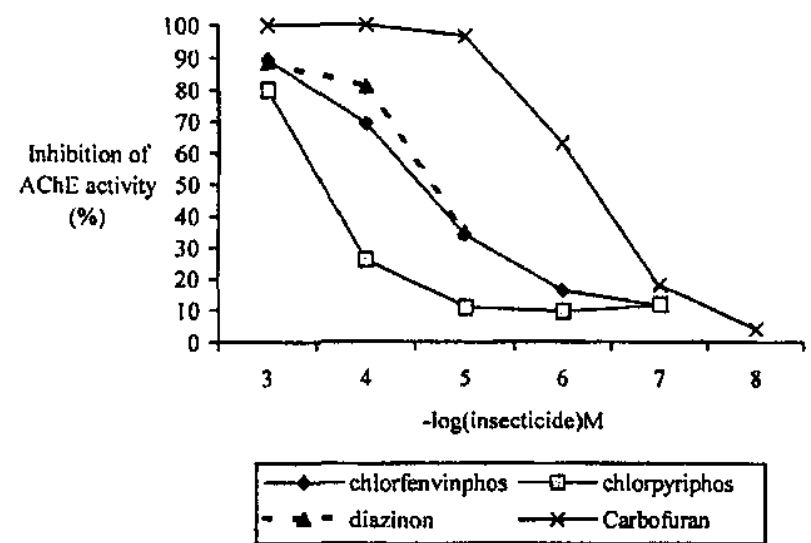

FIG. 1. Concentration - response of the common carp brain acetylcholinesterase (AChE) exposed to organophosphorous and carbamate. The result is expressed as a percentage of a control group. Each value is the mean of two replicated measurements. Point-to-point composite curves are provided to help visualization. At all concentrations tested the carbamate (carbofuran) caused more rapid inhibition than organosphophates (chlor-fenvinphos, chlorpyrifos, and diazinon).

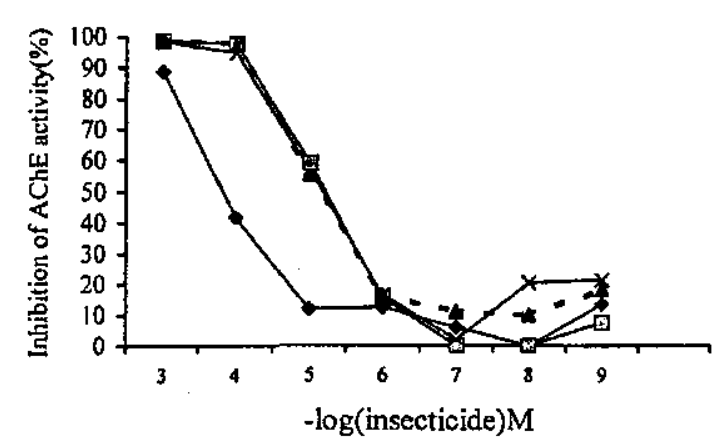

$\longrightarrow+1-8-2+\cdots 3-x-4$

FIG. 2. Concentration-response of common carp brain acetylcholinesterase (AChE) exposed to a mixture of organophosphates and carbamate. The result is expressed on a percentage of a control group. Each value is the mean of two replicated measurements. Point-to-point composite curves are provided to help visualization. The presence of car-bofuran in the mixture caused a more potent inhibition than that of organophosphates. 1, chlorfenvinphos-chlorpyrifos; 2, carbofuran-dia-zinon; 3 , carbofuran-chlorpyrifos; 4, carbofuran-chlorfenvinphos.

TABLE $1 I_{50}$ Values of Organophosphate and Carbamate Insecticides, and $I_{50}$ Values of Mixtures of Organophosphates and Carbamate on Cyprinus carpio Brain AChE

\begin{tabular}{|c|c|c|c|}
\hline Insecticides & $\mathrm{I}_{50}(\mathrm{M})$ & Insecticides mixtures & $\mathrm{I}_{50}(\mathrm{M})$ \\
\hline $\begin{array}{l}\text { Chlorfenvin } \\
\text { phos }\end{array}$ & $\begin{array}{l}1.9 \times 10^{-} \\
5\end{array}$ & $\begin{array}{l}\text { Carbofuran- } \\
\text { chlorfenvinphos }\end{array}$ & $6.9 \times 10^{-7}$ \\
\hline Chlorpyrifos & $8.1 \times 10^{-4}$ & Carbofuran-chlorpyrifos & $3.7+10^{-7}$ \\
\hline Diazinon & $1.9 \times 10^{-5}$ & Carbofuran-diazinon & $5.6 \times 10^{-7}$ \\
\hline Carbofuran & ${ }_{7}^{4.1 \times 10^{-}}$ & Chlorfenvinphos- & $9.8 \times 10^{-3}$ \\
\hline
\end{tabular}

Note: Acetylcholinesterase (AChE) inhibition was determined following 2 min of incubation at $25^{\circ} \mathrm{C}$ with a range from $10^{-2}$ to $10^{-}$ ${ }^{8} \mathrm{M}$. That includes concentrations giving between 10 and $90 \%$ of inhibition. Concentrations inhibiting AChE activity by $50 \%$ at that time and temperature $\left(I_{50}\right)$ were obtained by regression method (Finney, 1971).

All four groups tested with chlorfenvinphos exhibited significant inhibition of brain AChE activity. The observed inhibition ratio observed was higher than $80 \%$. The highest concentration induced $80 \%$ mortality after only $4 \mathrm{~h}$ (Table 3 ). The medium concentration $\left(4.9 \mathrm{mg}^{-\mathrm{L}^{-1}}\right)$ induced $100 \%$ mortality within $24 \mathrm{~h}$. With higher concentrations $\left(19 \mathrm{mg} . \mathrm{L}^{-1}\right)$ death occurred earlier in the experimental period. For chlorpyrifos, an $\mathrm{LC}_{50}$ of $0.49 \times 10^{-4} \mathrm{mg} . \mathrm{L}^{-1}$ was determined by log-probit analysis (Raymond, 1985). Three of the four concentrations $\left(14 ; 7.2 ; 3.6 \mathrm{mg}^{-\mathrm{L}^{-1}}\right)$ tested significantly inhibited brain AChE 
Published in : Ecotoxicology and environmental safety (2000), vol.

45 , iss. 1 , pp. 49-54

Status : Postprint (Author's version)

activity. A concentration three times the $\mathrm{LC}_{50}$ decreased brain AChE activity of the control group by $11.6 \%$. This concentration killed all fish after $4 \mathrm{~h}$ (Table 3$)$. The lowest concentration $\left(3.6 \times 10^{-4} \mathrm{mg}\right.$. $\mathrm{L}^{-1}$ ) killed only $30 \%$ of the test animals; the other $70 \%$ spent $96 \mathrm{~h}$ in contact with the insecticide and AChE activity decreased by about $85 \%$ of the control activity.

In the groups treated with two times the $\mathrm{LC}_{50}$ and $\mathrm{LC}_{50}$, at least seven fish spent $72 \mathrm{~h}$ in contact with insecticides and AChE activity decreased by about $75 \%$. The concentration two times $\mathrm{LC}_{50}$ showed $79 \%$ inhibition of the control group brain $\mathrm{AChE}$ activity, and a similar range was observed for the concentration $\mathrm{LC}_{50}$.

The concentration one-half the $\mathrm{LC}_{50}$ exhibited $86.4 \%$ inhibition of the control group AChE activity (Table 4).

For diazinon, $\mathrm{LC}_{50}$ determined by probit analysis method was estimated to be $0.72 \times 10^{-4} \mathrm{mg}^{\prime} \mathrm{L}^{-1}$. The concentration three times $\mathrm{LC}_{50}$ induced no inhibition. All 10 fish died after $4 \mathrm{~h}$. The three other concentrations revealed different inhibitory levels. The two times $\mathrm{LC}_{50}, \mathrm{LC}_{50}$, and one-half $\mathrm{LC}_{50}$ indicated 18.3, 58, and 49\% inhibition, respectively, compared to control group brain AChE (Table 4). The concentration two times $\mathrm{LC}_{50}$, killed $70 \%$ of the fish before $72 \mathrm{~h}$. In the two other concentration groups about $80 \%$ of the fish spent $96 \mathrm{~h}$ in contact with the insecticide.

The first concentration of carbofuran $\left(10^{-3} \mathrm{mg} . \mathrm{L}^{-1}\right)$ exhibited no significant difference in activity with that of the control group. All 10 fish died $4 \mathrm{~h}$ after exposure. Fish exposed to $0.22 \times 10^{-3} \mathrm{mg} . \mathrm{L}^{-1} \mathrm{die}$ after $24 \mathrm{~h}$; in this group the decrease in AChE activity was $75 \%$. The two other concentration groups, $0.1 \times 10^{-3} \mathrm{mg} . \mathrm{L}^{-1}$ and $0.05 \times 10^{-3} \mathrm{mg} . \mathrm{L}^{-1}$, induced 27.8 and $64.5 \%$ inhibition, respectively, compared to control group brain AChE activity (Table 4).

TABLE 2 Control Group Brain Acetylcholinesterase Activity (mM/min/mg Protein)

\begin{tabular}{ll}
\hline Control $_{1}$ & AChE \\
$\mathrm{Control}_{2}$ & $2.20 \times 10^{-3}$ \\
$\mathrm{Control}_{3}$ & $1.64 \times 10^{-3}$ \\
\hline Note Carp in control group were exposed to water without insecticide for $96 \mathrm{~h}$ at $8+2^{\circ} \mathrm{C}$. After the exposu
\end{tabular}

Note. Carp in control group were exposed to water without insecticide for 96 h at $8+2{ }^{\circ} \mathrm{C}$. After the exposure period the 10 fish were sacrificed and brain AChE was extracted. Three measurements per brain were performed. Contrail represented the controls of the first week and control-represented those of the second week.

TABLE 3 Mortality (\%) related to Exposure Period (96 h)

\begin{tabular}{|c|c|c|c|c|c|}
\hline Pesticide & $\begin{array}{l}\text { Concentration } \mathrm{x} \\
10^{-4} \\
\left(\mathrm{mg} . \mathrm{L}^{-1}\right)\end{array}$ & $24 \mathrm{~h}$ & $48 \mathrm{~h}$ & $72 \mathrm{~h}$ & $96 \mathrm{~h}$ \\
\hline Carbofuran $_{1}{ }^{a}$ & 10 & 100 & 0 & 0 & 0 \\
\hline Carbofuran2 & 2.2 & 100 & 0 & 0 & 0 \\
\hline Carbofuran $_{2}$ & 1 & 0 & 0 & 0 & 0 \\
\hline Carbofuran1 & 0.5 & 20 & 0 & 0 & 0 \\
\hline Diazinon $_{1}{ }^{a}$ & 15 & 100 & 0 & 0 & 0 \\
\hline Diazinon $_{2}$ & 7.9 & 20 & 10 & 40 & 0 \\
\hline Diazinon $_{2}$ & 3.9 & 10 & 10 & 0 & 0 \\
\hline Diazinon $_{1}$ & 1.9 & 0 & 10 & 0 & 0 \\
\hline $\begin{array}{l}\text { Chlorfenvinph } \\
\text { os }_{1}\end{array}$ & 19 & 80 & 10 & 10 & 0 \\
\hline $\begin{array}{l}\text { Chlorfenvinph } \\
\text { os }_{1}\end{array}$ & 9.8 & 70 & 0 & 20 & 0 \\
\hline $\begin{array}{l}\text { Chlorfenvinph } \\
\mathrm{os}_{2}\end{array}$ & 4.9 & 100 & 0 & 0 & 0 \\
\hline $\begin{array}{l}\text { Chlorfenvinph } \\
\text { os }_{2}\end{array}$ & 2.4 & 20 & 0 & 0 & 0 \\
\hline Chorpiryfos $2^{\mathrm{a}}$ & 29 & 100 & 0 & 0 & 0 \\
\hline Chorpiryfos $_{1}$ & 14 & 20 & 20 & 10 & 20 \\
\hline Chorpiryfos 2 & 7.2 & 40 & 10 & 0 & 0 \\
\hline
\end{tabular}


Published in : Ecotoxicology and environmental safety (2000), vol.

45 , iss. 1 , pp. 49-54

Status : Postprint (Author's version)

$\begin{array}{llllll}\text { Chorpiryfos } & 3.6 & 0 & 30 & 0 & 0\end{array}$

Note. The highest concentration killed all the fish and the lowest killed at least $30 \%$. Carp were exposed to four different concentrations of car-bofuran, chlorfenvinphos, chlorpyrifos, and diazinon. Exposure was performed in concentrations able to kill fish after $4 \mathrm{~h}$ or up to 4 days exposure period. The activity of brain AChE was measured and compared to controls.

${ }^{a}$ Concentration that induced $100 \%$ mortality after $4 \mathrm{~h}$.

TABLE 4 Dunnett Test Result

\begin{tabular}{|c|c|c|c|c|}
\hline Pesticide & $\begin{array}{l}\text { Concentration } \times 10^{-4} \\
\left(\mathrm{mg} . \mathrm{L}^{-1}\right)\end{array}$ & 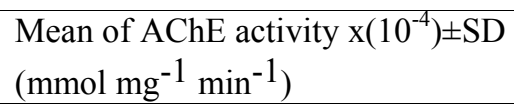 & $\%$ Activity/control & \\
\hline $\begin{array}{l}\text { Carbofur } \\
\text { an } 1\end{array}$ & 10 & $24.8 \pm 0.2$ & 116.7 B & 3.5 \\
\hline $\begin{array}{l}\text { Carbofur } \\
\text { an } 2\end{array}$ & 2.2 & $5.5 \pm 0.2$ & $25.8 \mathrm{C}$ & $15.8^{*}$ \\
\hline $\begin{array}{l}\text { Carbofur } \\
\text { an } 2\end{array}$ & 1 & $15.4 \pm 0.2$ & $72.6 \mathrm{D}$ & 5.8 \\
\hline $\begin{array}{l}\text { Carbofur } \\
\text { an } 1\end{array}$ & 0.5 & $7.9 \pm 0.2$ & $37.0 \mathrm{C}$ & $13.4^{*}$ \\
\hline $\begin{array}{l}\text { Diazinon } \\
1\end{array}$ & 1.5 & $25.8+0.2$ & $121-4 \mathrm{~B}$ & 4.5 \\
\hline $\begin{array}{l}\text { Diazinon } \\
2\end{array}$ & 7.9 & $17.3 \pm 0.2$ & $81.4 \mathrm{C}$ & 3.9 \\
\hline $\begin{array}{l}\text { Diazinon } \\
2\end{array}$ & 3.9 & $8.8 \pm 0.2$ & $41.3 \mathrm{C}$ & $12-5 *$ \\
\hline $\begin{array}{l}\text { Diazinon } \\
1\end{array}$ & 1.9 & $12.0 \pm 0.3$ & $56.3 \mathrm{C}$ & 9.2 \\
\hline $\begin{array}{l}\text { Chlorfen } \\
\text { vinphos } 1\end{array}$ & 19 & $1.1 \pm 0.3$ & $5.2 \mathrm{C}$ & $20.1^{*}$ \\
\hline $\begin{array}{l}\text { Chlorfen } \\
\text { vinphos } 1\end{array}$ & 9.8 & $2.1 \pm 0.2$ & $9.8 \mathrm{C}$ & $19.2^{*}$ \\
\hline $\begin{array}{l}\text { Chlorfen } \\
\text { vinphos } 2\end{array}$ & 4.9 & $1.3 \pm 0.2$ & $6.3 \mathrm{C}$ & $19.9^{*}$ \\
\hline $\begin{array}{l}\text { Chlorfen } \\
\text { vinphos } 2\end{array}$ & 2.4 & $1.7 \pm 0.2$ & $8.0 \mathrm{C}$ & $19.5^{*}$ \\
\hline $\begin{array}{l}\text { Chorpiryf } \\
\text { os } 2\end{array}$ & & $18.6 \pm 0.2$ & $87.6 \mathrm{~B}$ & 2.6 \\
\hline $\begin{array}{l}\text { Chorpiryf } \\
\text { os } 1\end{array}$ & 14 & $5.1 \pm 0.2$ & $24.2 \mathrm{C}$ & $16.1 *$ \\
\hline $\begin{array}{l}\text { Chorpiryf } \\
\text { os } 2\end{array}$ & & $4.7 \pm 0.2$ & $22.2 \mathrm{C}$ & $16.5^{*}$ \\
\hline $\begin{array}{l}\text { Chorptryf } \\
\text { os } 1\end{array}$ & & $2.9 \pm 0.2$ & $13.8 \mathrm{C}$ & $18.3^{*}$ \\
\hline \multicolumn{5}{|c|}{ 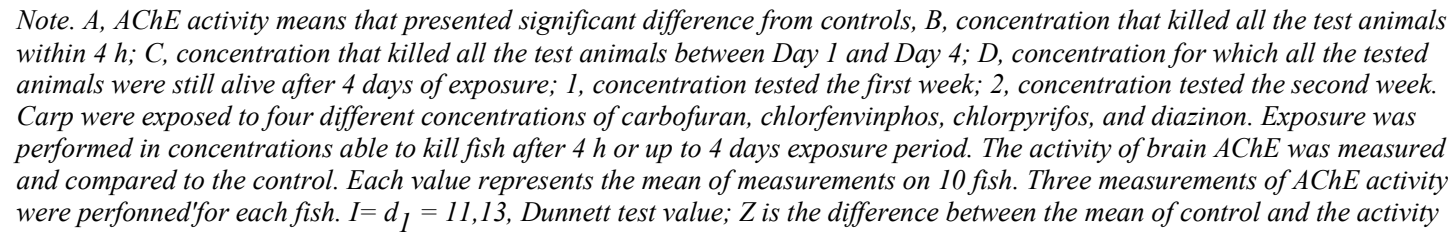 } \\
\hline
\end{tabular}

\section{DISCUSSION}

It is worth noting that, in in vitro inhibitory tests, all of the pesticides inhibited the enzyme by at least $20 \%$ at a concentration of $10^{-3} \mathrm{M}$. Similar results were observed by Bastos et al. (1991) for other organophosphates and carbamates.

The observed values of $\mathrm{I}_{S O}$ are in agreement with those observed with carbofuran and carbaryl on common prawn (Bocquene et at, 1995).

When two insecticides were mixed it was noted that the effect of the lowest inhibitor of the two was enhanced. It was also observed that when chlorfenvinphos was combined with carbofuran, the $\mathrm{I}_{50}$ represented $3.6 \%$ of its value compared to chlorfenvinphos alone. In the case of chlor-pyrifos, the $\mathrm{I}_{50}$ 
Published in : Ecotoxicology and environmental safety (2000), vol. 45 , iss. 1 , pp. 49-54

Status : Postprint (Author's version)

was reduced to $12 \%$ of its value. Diazinon and chlorpyrifos exhibited a synergistic effect when combined with carbofuran. The percentage of cabofuran used was $90 \%$ (oftheI 50 when used alone) and only $0.04 \%$ of the $\mathrm{I}_{50}$ of chlorpyrifos. It qualified as a synergistic interaction. When diazinon was associated with carbofuran, the $\mathrm{I}_{S O}$ (concentration that inhibited $50 \%$ of AChE activity) was in the same range of that of carbofuran used alone. Although $2.9 \%$ of the $\mathrm{I}_{50}$ of diazinon was added, this association seemed to have no interaction. Carbofuran appeared to be the most efficient inhibitor $\left(I_{50}=\right.$ $\left.4.1 \times 10^{-7} \mathrm{M}\right)$ compared to the other pesticides tested $\left(I_{50}>4.1 \times 10^{-7} \mathrm{M}\right)$. A similar result was reported by Bocquene et al (1995). Chlorfenvinphos and diazinon are moderate inhibitors, whereas chlor-pyrifos is a weak inhibitor This observation on chlorpyrifos is in agreement with the work of Bocquene et al. (1995) and Olson and Christensen, (1980), who reported that many organophosphate pesticides are less efficient inhibitors before becoming metabolically transformed from thio to oxy analogs.

The abnormalities in fish behavior observed in this study could be related to failure of energy production or the release of stored metabolic energy, which may cause severe stress, leading to the death of the fish (Chakraborty et al., 1989).

Treating carp with chlorfenvinphos, chlorpyrifos, carbo-furan, and diazinon caused modification of acetylcholinesterase activity. Some marked differences in efficiency are indicated between the insecticides examined when tested with the Dunnett test pagnelie, 1975). The fish that died within $4 \mathrm{~h}$ after exposure of OP and $\mathrm{C}$ generally revealed no statistical difference with the control group. These results can be explained by death of the fish by asphyxia or irritation of the gill (Pesson, 1976). With chlorfenvinphos, the inhibitory action was proportional to the concentration and the time of exposure. The quicker the fish died, the lower the inhibition rate was. The same observation was found for chlopyriphos and diazinon. Those differences can be explained by the fact that chlorpyrifos and diazinon are the two sulfite forms and the duration in the water induced their oxidation to the more inhibitory oxon form.

In vivo the activation of the thiono-type $\mathrm{OPs}$ is mainly due to photolysis. Phosphorothionate $(\mathrm{P}=\mathrm{S})$ pesticides such as chlorpyrifos are converted into their oxygen analog, oxon $(\mathrm{P}=0)$, by different degradation pathways, including proteolysis, before becoming strongly irreversible inhibitors (Bocqueneet $a l, 1995)$.

\section{CONCLUSION}

In conclusion, although the highest concentrations of cabofuran and diazinon killed all the fish, this occurred without a significant decrease in brain AChE activity. It is well established by this study that the chronic exposure to all tested insecticides in aquatic medium can significantly depress the AChE level in the brain. This level of depression induced by chronic exposure can be used as a biomarker to predict agrochemical pollution. Further work is needed to determine the specific effect of high concentrations of insecticides that kill fish without inhibiting brain AChE, and the reaction of $\mathrm{AChE}$ in field conditions.

\section{Acknowledgments}

The authors thank Pr_J.-P. Toutant (INRA, Montpeliier, France) and Dr. Andreas Boczick (Department of Plant Protection, University of Agricultural Science, Debrecen 4015, Hungary) Tor helpful comments on the manuscript and Pr. Claustriaux Jean Jacques (Unite de Statistique et Informatique, FUSAGx, Gembloux Belgium) for contribution to the experimental design. A scholarship to the first author was provided by the Scientific Research Ministry of Ivory Coast.

\section{References}

Bastos, V. L. F. C, Bastos, C, Lima, J. S., and Faria, M. C V. (1991). Brain acetylcholinesterases as an in vitro detector of organophosphorus and carbamate insecticides in water. Wat. Res. 25, 835-840.

Bocquene, G., Bellanger, C, Caudiou, Y, and Galgani, F. (1995). Joint action of combination pollutants on the acetylcholinesterase activity of several marine species. Environ. Toxicol. Chem. 4, 266-279. 
Published in : Ecotoxicology and environmental safety (2000), vol.

45 , iss. 1 , pp. 49-54

Status : Postprint (Author's version)

Chakraborty, P. S., Malltk, A., Dingal, K. D., and Banerjee, S. (1989). Effect of methyl parathion on brain and olfactory organ acetylcholinesterase activity of the fish Heteropneustes fossilis. Environ. Ecotoxicol. 7, 310-314.

Cook, G. H, Moore, C J., and Coppage, D, L. (1976). The relationship of malathion and its metabolites to fish poisoning. Bull Environ. Contam. Toxicol 6, 283-290.

Coppage, D. L., and Braidech, T. E. (1976). River pollution by anticholinesterase agents. Wat. Res. 10, 19-24.

Coppage, D. L., and Mathews, E, (1974), Shorten effect of organophosphate pesticides on cholinesterase of estuarine fishes and pink shrimp. Bull Environ. Contam. Toxicol. 11, 483-487.

Dagnelie, P. (1975). Theorie et methodes statistiques, 2nd ed. Presse Agronomique de Gembloux, Gembloux, Beigium.

Ellman, G. L., Courtney, K. D., Andres V. Jr., and Featherstone, R. M. (1961). A new and rapid colorimetric determination of acetylcholines-trase activity. Biochem. Pharmacol 7, 88-95.

Finney, D. J. (1971). Probit Analysis, 3rd ed. Cambridge Univ. Press, London.

Hart, A. D. M. (1993). Relationships between behavior and the inhibition of acetylcholinesterase in birds exposed to organophosphorus pesticides. Environ. Toxicol. Chem. 12, 321-336.

Lowry, O. H., Rosebroucgh, N. J., Farr, A. L., and Randall, R. (1951). Protein measurement with folin phenol reagent. J. Biol. Chem. 193, 193-265.

OCDE (1981). OCDE Guideline for Testing of Chemicals. Organization for Economic Cooperation and Development. Report. No. 203 and 204. OCDE, Paris.

Olson, D. L., and Christensen, G. M. (1980). Effect of water pollutants and other chemicals on fish acetylcholinesterase (in vitro). Environ. Res. 21,327-335.

Peakall, D. B., and Shugart, L. R. (1991). Blomarkers Research and Application in Assessment of Environmental Health (D. B. Peakall and L. R. Shugart, Eds.). Springer-Verlag, The Netherlands. Pesson, P. (1976). La pollution des eaux commentates (Bordas, Ed.). Gauthicr, Villars, Pairs.

Raymond, M. (1985). Presentation d'un programme d'analysc log-probit pour micro-ordinateur. Cahier ORSTOM 22, 117-121.

Sahib, I. K. A., and Rao, K. V. R. (1980). Correlation between subacute toxicity of malafhion and acetylcholinesterase inhibition in the tissues of the teleost Tilapia mossambica. Bull Environ. Contam. Toxicol 24, 711-718.

Sharma, B., Gopal, K., and Khana, Y. P. (1993). Interaction of carbaryl with acetylcholinesterase of the teleost Clarias batrachus. Toxicol Environ. Chem.39, 147-152.

Westlake, G. E., Bunyan, J. P., Martin, A. D., Stanley, D., and Steed, L. C (1981a). Carbamate poisoning: Effects of selected carbamates pesticides on plasma enzymes brain esterase of Japanese quail (Coturnix coturnix japonica). J. Agric. Food. Chem. 29, 779-785.

Westlake, G. E., Bunyan, J. P, Martin, A. D., Stanley, D-, and Steed, L. C (1981b). Organophosphatc poisoning: Effects of selected organophos-phate pesticides on plasma enzymes brain esterase of Japanese quail (Coturnix coturnix japonica). J. Agric. Food. Chem. 29, 772-778. 